IZA DP No. 7553

Entrepreneurship and the Business Environment in Africa: An Application to Ethiopia

Zuzana Brixiova

Mthuli Ncube

August 2013 


\title{
Entrepreneurship and the Business Environment in Africa: An Application to Ethiopia
}

\author{
Zuzana Brixiova \\ African Development Bank \\ and IZA \\ Mthuli Ncube \\ African Development Bank \\ Discussion Paper No. 7553 \\ August 2013 \\ IZA \\ P.O. Box 7240 \\ 53072 Bonn \\ Germany \\ Phone: +49-228-3894-0 \\ Fax: +49-228-3894-180 \\ E-mail: iza@iza.org
}

\begin{abstract}
Any opinions expressed here are those of the author(s) and not those of IZA. Research published in this series may include views on policy, but the institute itself takes no institutional policy positions. The IZA research network is committed to the IZA Guiding Principles of Research Integrity.

The Institute for the Study of Labor (IZA) in Bonn is a local and virtual international research center and a place of communication between science, politics and business. IZA is an independent nonprofit organization supported by Deutsche Post Foundation. The center is associated with the University of Bonn and offers a stimulating research environment through its international network, workshops and conferences, data service, project support, research visits and doctoral program. IZA engages in (i) original and internationally competitive research in all fields of labor economics, (ii) development of policy concepts, and (iii) dissemination of research results and concepts to the interested public.
\end{abstract}

IZA Discussion Papers often represent preliminary work and are circulated to encourage discussion. Citation of such a paper should account for its provisional character. A revised version may be available directly from the author. 
IZA Discussion Paper No. 7553

August 2013

\title{
ABSTRACT
}

\section{Entrepreneurship and the Business Environment in Africa: An Application to Ethiopia ${ }^{1}$}

\begin{abstract}
Since mid-2000s, Ethiopia has been one of the fastest growing countries in the world. However, productive entrepreneurship in high-value added activities has made limited contributions to this growth, in part because of a weak business environment. Moreover, the low-productive firms in the informal sector still account for a large share of employment. Reflecting these facts, this paper presents a model of costly entrepreneurial start-ups in an economy with a large informal sector and rigid business environment where an equilibrium outcome can be a low-skill, low-productivity trap. By fostering productive start-ups and skilled employment, creation of an enabling business environment could help move the Ethiopian economy into high-productivity equilibrium.
\end{abstract}

JEL Classification: L26, J24, J48, O17

Keywords: entrepreneurship, SME start-ups, low productivity trap, multiple equilibria, Africa

Corresponding author:

Zuzana Brixiova

African Development Bank

15 Avenue du Ghana

P.O. Box 323-1002

Tunis-Belvedère

Tunisia

E-mail: z.brixiova@afdb.org

\footnotetext{
1 The authors thank Emerta Asaminew and Andreas Wörgötter for comments and inputs into the earlier version (AfDB Working Paper No. 117). The paper was presented at the African Economic Conference (Addis Ababa, 2009), the IZA/World Bank Conference on Employment and Development (Cape Town, 2010) and the 2011 Conference of South African Economic Society (Stellenbosch). The views expressed are those of the authors and do not necessarily reflect those of the African Development Bank.
} 


\section{Introduction}

Policymakers in Africa have long recognized the private sector, including entrepreneurship, to be a key part of development agenda for their countries and the continent. Despite this recognition, contribution of productive entrepreneurship to growth and employment has been limited, especially in low income and fragile countries. While entrepreneurship as such has not been limited in Africa, the productive, high value-added type has been mostly missing (Rogerson, 2001). One of the reasons has been lower competitiveness in a number of African countries, stemming in part from an overall weaker business environment than in other regions. Raising competitiveness through improving the business environment is thus a top policy priority in Africa.

In Ethiopia, the private sector gained more prominence in 1991, after the socialist Derg regime was replaced. The subsequent government introduced market reforms with a view to stimulate growth through a vibrant private sector, especially small and medium enterprises (SMEs). Two decades later, however, the record has been mixed. While Ethiopia has been among the fastest growing countries in the world since the mid-2000s, public enterprises and low productive firms in the informal sector employ majority of the population. Highly productive SMEs can be found mostly in selected sectors and regions. In sum, the rapid growth driven by public investment, agriculture and a few exceptional sectors notwithstanding, a large part of the country experiences high unemployment, low productivity, low-paid jobs, and poverty. Developing the country's private sector and productive SMEs is thus a key policy challenge.

This paper develops a model of costly entrepreneurial start-ups in an economy with rigid business environment and a large and dualistic informal sector. This line of research contributes to closing a gap in the 'entrepreneurship and development' literature, which consists mostly of empirical studies and surveys, but theoretical underpinning has been mostly lacking. The model extends and applies the framework of Brixiová (2013) to the case of a low income country. The model also builds on Snower (1996) who showed for developed countries that labor market failures, including imperfect information, lead to suboptimal outcomes. Such failures are even

more prevalent in low-income countries such as Ethiopia where the business environment is weak and the labor market including supporting institutions underdeveloped. Specifically, entrepreneurs are discouraged from search for a productive business opportunity because of the weak business environment and the potential difficulties in finding skilled workers. Similarly, workers are not always aware of skilled vacancies. The product and labor market imperfections hamper development of the highly-productive private sector employing skilled labor. In linking the model with data and other evidence on business environment, we draw on Ncube (2005).

The paper focuses on entrepreneurial start-ups of highly-productive firms, as their absence constraints output and job growth in Ethiopia. We show how under a weak business environment the economy can end up in a low productivity trap, with the informal sector accounting for all private sector output and employment. The emphasis on firm creation and the inclusion of the informal sector, which characterize Ethiopia and other low-income countries, distinguish this framework from that of Snower (1996) who analyzed vacancies in existing firms in the formal sector in advanced economies. It also differs from that of Gelb et al. (2008) by considering how regulations, in particular unclear property rights, can impact the entrepreneurial search and drive 
firms to the informal sector. The model reflects key stylized facts of the Ethiopian urban labor market. We utilize it to examine policies that could support development of highly productive SMEs in the formal sector and move the economy into high productivity equilibrium.

The paper is organized as follows. After this Introduction, Section II highlights stylized facts on the SME sector and the urban labor market in Ethiopia. Section III presents the model and examines the impact of a better business environment on SME start-ups. Section IV confronts the results with empirical evidence from other developing countries. Section V concludes.

\section{Growth and SME Constraints in Ethiopia: The Facts}

Since Ethiopia introduced market reforms in 1991, its economy has been characterized by mix of market incentives and central planning. The heavy role of the state sector in the non-agricultural output and low job creation in the formal private sector make the country akin to an early-stage transition economy. At the same time, Ethiopia exhibits characteristics of a typical low income country, such as a large and dualistic informal sector; high share of agriculture in the output; and the lack of enabling business environment, among others. The paragraphs below highlight main facts about challenges to growth and productive entrepreneurship in the country.

\section{Growth and Productivity Trends}

At average annual growth of 10.4 percent during 2005 - 2011, Ethiopia was one of the fastest growing countries in Sub-Saharan Africa (SSA) and globally during this period (Table 1). However, growth was driven mostly by modernization of agriculture (which accounts for 80 percent of employment), commodity boom, public investment, and - with the exception of financial intermediation - expansion of low value-added services (Geiger and Moller, 2013). For the most part, performance of the manufacturing sector and high-value added services remained subdued. ${ }^{2}$ The manufacturing subsector contributed less than 4 percent of output in 2012.

Table 1: Real GDP Growth: Ethiopia and other SSA countries

\begin{tabular}{lcccc}
\hline & \multicolumn{2}{c}{$1991-2004$} & $2005-2011$ \\
Growth (\%) & SD & Growth (\%) & SD \\
\hline Angola & 3.7 & 2.9 & 12.5 & 0.7 \\
Ethiopia & $\mathbf{3 . 6}$ & $\mathbf{2 . 0}$ & $\mathbf{1 0 . 4}$ & $\mathbf{0 . 2}$ \\
Rwanda & 3.7 & 4.2 & 7.9 & 0.3 \\
Equatorial Guinea & 35.6 & 1.1 & 7.9 & 0.9 \\
Liberia & -4.2 & 3.8 & 7.7 & 0.4 \\
Ghana & 4.6 & 0.1 & 7.6 & 0.4 \\
Uganda & 6.4 & 0.4 & 7.5 & 0.2 \\
Mozambique & 7.3 & 0.7 & 7.4 & 0.1 \\
Tanzania & 4.1 & 0.6 & 6.9 & 0.1 \\
Nigeria & 4.9 & 1.2 & 6.7 & 0.1 \\
\hline
\end{tabular}

\footnotetext{
2 After the government provided technology packages and support services to smallholder farmers, yields have risen. Agricultural was boosted by expansion in the area under cultivation. During the 2003/04-2008/09 agricultural production grew annually at 9.3 percent while cultivated area expanded at 4.7 percent (AfDB et al., 2012).
} 
Source: Authors' calculations based on the AfDB and IMF databases.

Despite the growth surge, productivity growth has remained low and wide productivity gaps between Ethiopia and East Asia economies (e.g., China or India) as well as some African frontier markets (e.g., Mozambique or Uganda) persisted (Figure 1).

Figure 1a. Labor Productivity Index

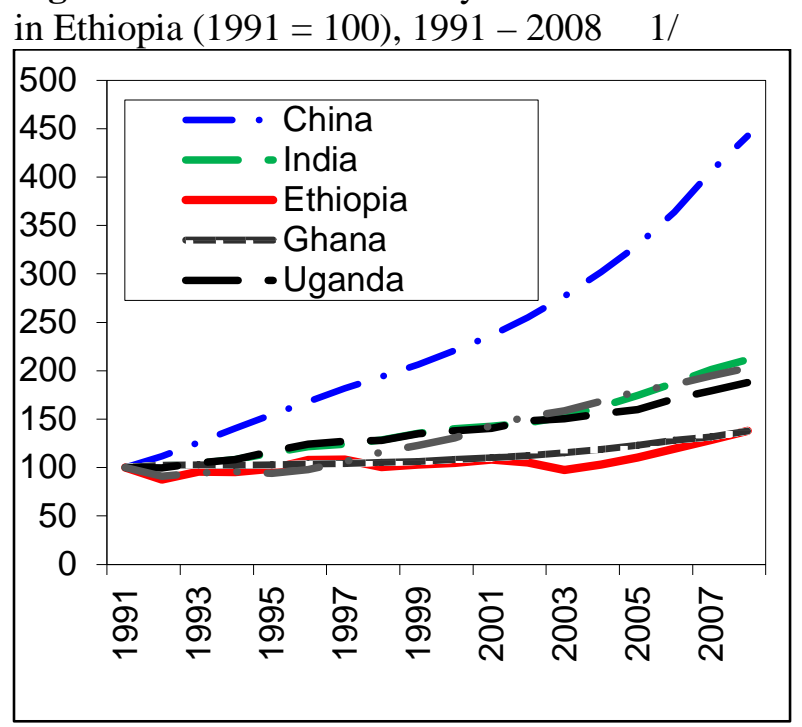

Figure 1b. Productivity Levels in Ethiopia, Mozambique, and Uganda, 1991 and 2008 1/

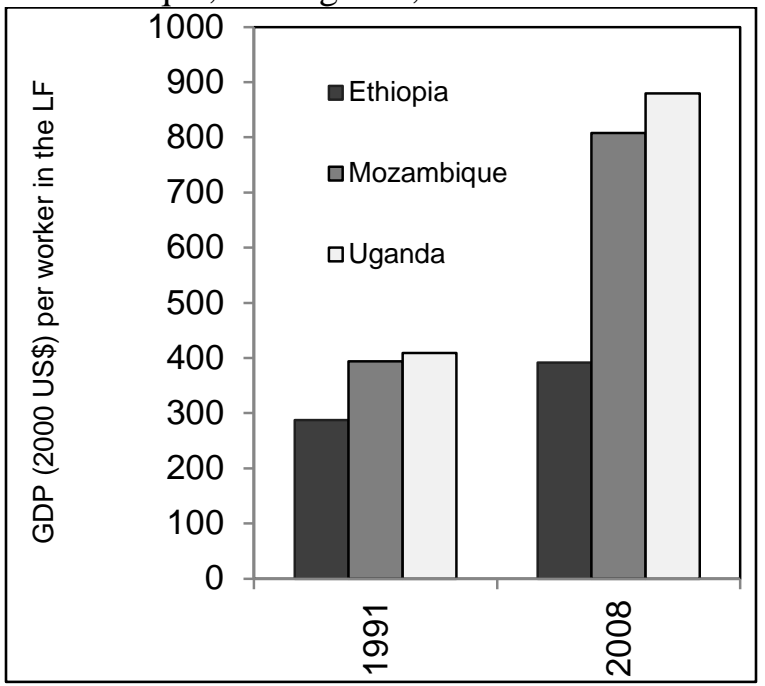

Source: Authors' calculations based on the ILO database and the AEO 2012. 1/ Labor productivity is measured as GDP (in 2000 US\$) per worker.

Ethiopia's growth was based on high levels of public investment (in infrastructure, public enterprises), while private sector drivers of growth have been neglected. ${ }^{3}$ Growth accounting revealed that public investment accounted for most of the growth recorded since mid-2000s, and specifically for 2/3 in 2011/2012 (IMF, 2012, and Geiger and Moller, 2013). In contrast, in the rest of SSA expansion has been driven by commodity prices, both public and private investment, and robust private consumption. More important, the heavy reliance of the Ethiopia's economic performance on public investment and the burden it has put on the country's public finance have risen questions about sustainability of the country's growth. In fact, projections already indicate growth slowdown for 2013 and 2014 (AfDB et al, 2013). To achieve high and sustained growth and reach middle-income status by 2025, the private sector will need to drive growth.

\section{Business Environment and SME Constraints}

The Ethiopian private sector has evolved in stages. ${ }^{4}$ First, central planning-based policy of the socialist Derg regime during 1974-1990 discouraged private sector activities. In contrast, the subsequent government favored implementing market reforms, to cut bureaucratic procedures and encourage rapid growth of the private sector (Geda and Degefe, 2002).

\footnotetext{
${ }^{3}$ As IMF stated in its 2012 country report '...Ethiopia pursues a public sector-led growth strategy that focuses on promoting growth through high public investment...' (IMF, 2012, page 4).

${ }^{4}$ The private sector includes all agents in the economy not formally classified as in the public sector that is agents involved in the government, state-owned enterprises or parastatals, and independent public agencies.
} 
Two decades later, productive entrepreneurship blossoms only in a few sectors (leather, flowers) and is limited elsewhere, while the share of the state sector in industrial output has stagnated around 50 percent since 2000. Most SMEs are private, but very small, informal and low productivity firms, operating mostly in services, predominate. ${ }^{5}$ Going forward, dynamic private sector will need to play more prominent role for growth to accelerate or at least be sustained.

The lack of an enabling business environment seems to be one of the factors behind a suppressed private sector in the country. By the business environment, we mean institutions and policies that affect firm entry, survival, growth and exit. Since our analysis focuses on new firms, we pay of course attention to barriers to entry, while recognizing that the expected profit and difficulties to exit also influence decisions at the start-up phase. The two main barriers to firm creation are the administrative burdens related to starting a business and access to finance, while the government interference and the tax system impact the expected profit and firm survival (Lopez-Garcia, 2006)

The private firm creation in Ethiopia is impeded by a number of structural obstacles, including credit constraints and trade barriers, a weak judiciary and regulatory framework, and complicated land registry. In the 2013 World Bank Doing Business report, Ethiopia ranked as \#127 out of 185 countries, a decline from \#97 in 2007. ${ }^{6}$ On a positive side, the government has simplified business registration and investment licensing procedures and has undertaken other changes to regulatory institutions that notably reduced the cost of doing business (World Bank, 2013). On a less positive side investor protection seems to have weakened. The country also continues to exhibit weaknesses in the category 'Starting a Business' (ranking as \#163 out of 184 countries), mostly due to very high start-up cost and required minimum capital (Figure 2 and Table 2).

Table 2. Indicators of Starting a Business: Ethiopia and Other African Countries

\begin{tabular}{lcccccc}
\hline & Ethiopia & Average & Average & & & \\
& SSA & EAC & Rwanda & Mauritius & Madagascar \\
\hline Rank (out of 184) & 163 & 123 & 84 & 8 & 14 & 17 \\
Procedures (\#) & 9 & 8 & 8 & 2 & 5 & 2 \\
Time (days) & 15 & 34 & 20 & 3 & 6 & 8 \\
Cost (\% of income per capita) & 135 & 67 & 34 & 4 & 3 & 11 \\
Min. Capital (\% of income per capita) & 249 & 116 & 0 & 0 & 0 & 0 \\
\hline
\end{tabular}

Source: Authors’ calculations based on World Bank’s Doing Business 2013.

\footnotetext{
${ }^{5}$ The thriving leather industry is one of the exceptions. In the early 2000s, leather-show industry has gained a substantial share in the domestic market, with its growth being driven by new entrants and expansion of incumbents (Sonobe et al., 2009). Recently, with the government support, Ethiopia has been successfully exporting high-value, finished leather products into OECD economies (USAID, 2009).

${ }^{6}$ The World Bank Doing Business indicators, while widely used, have also received their share of criticism as a measure that would guide government reform priorities. For example, Pineheiro-Alves and Zambujal-Oliviera (2012) that the indicators show limited consistency and prescriptive power for policy making, in part because many of them depend on 1-2 variables. Arrunada (2007) argues that besides statistical weaknesses, the indicators focus only on costs on regulatory institutions and do not adequately capture the benefits - including information - they generate. Acknowledging these weaknesses, Hanusch (2012) posits that governments can nevertheless use Doing Business reports for reforms and finds that indicators related to costs have the largest potential for fostering growth.
} 
The information on barriers to start-ups from the Doing Business are complemented by those of the 2011 Ethiopia Enterprise Survey of the World Bank, where access to finance and to land were key obstacles for small (with 1-19 employees) and medium-sized (with 20 - 99 employees) firms. Specifically, 40 percent of small and 30 percent of medium-sized firms reported access to finance as key obstacle to their operations. About one out four of the firms viewed access to land as a key obstacle to their activities. Further, more than 20 percent of the country's SMEs identified tax rates and tax administration as a major constraint to their operations. Access to electricity was also viewed as a barrier. These messages were echoed in the 2012-2013 Global Competitiveness Report, where investors identified (i) access to finance, (ii) corruption, and (iii) inefficient government bureaucracy as three most problematic factors for doing business. ${ }^{7}$

Figure 2a. Cost of Starting a Business (\% of income per capita)

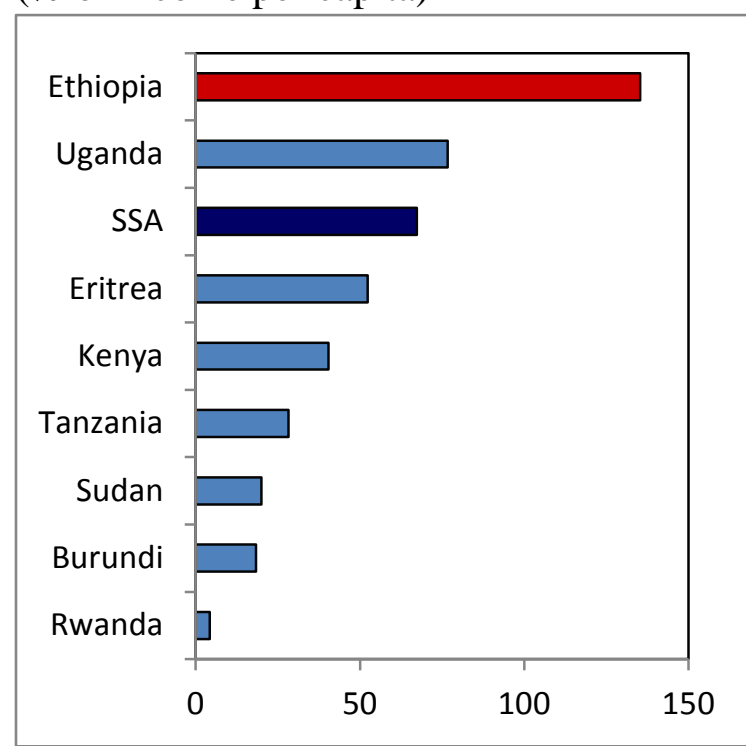

Source: World Bank Doing Business 2013.
Figure 2b. Paid-in Minimal Capital (\% of income per capita)

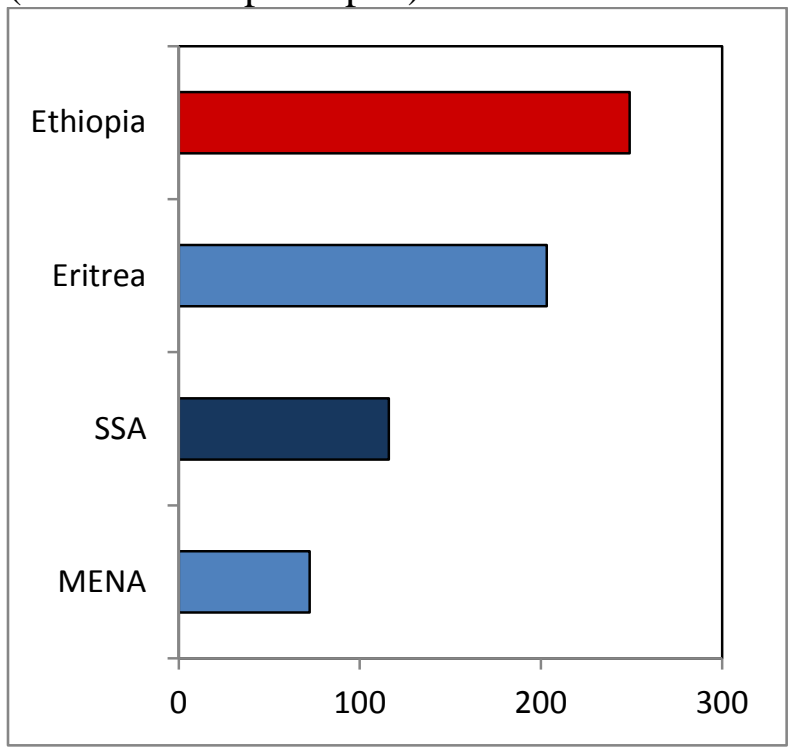

\section{Skill Mismatches}

The urban labor market has been characterized by high unemployment, especially among youth (Figure 3), while the exit rates from the unemployment pool to the private sector have been low. On the supply side, the contributing factors included a rapidly growing urban population, which more than doubled between 1990 and 2007, from about 6 to 13 million and the declining public sector. Only about half of the total urban population employed in the formal sector was in the private sector. The regional distribution was also uneven, with most of the private sector concentrated in and around Addis Ababa (Ethiopian Central Statistical Office, various reports). ${ }^{8}$

\footnotetext{
7 SME constraints can also vary across sectors and locations within the country, as documented in Dollar et al. (2005) and others. Egan (2008) utilized example of small business owners in retail clothing industry in Addis Ababa to demonstrate main constraints to efficiency and profitability for existing SMEs in this sector. He found them to be corruption, the lack of finance and human resources. Sutton and Kellow (2010) map enterprises across various sectors.

${ }^{8}$ To put Ethiopia's private sector in perspective, a comparison with regional peers and other transition economies may be useful. In Tanzania, the private sector has been the main driver of growth, and it accounted for about 70
} 
The Ethiopian labor market has been also characterized by mismatches between skills supplied by the educational system and those demanded by the private sector, as evidenced by high unemployment rates of young people with high school and higher education (Figure 3). Moreover, $1 / 5$ of vacancies in the early 2000s remained unfilled, due to the lack of skilled workers or their unwillingness to relocate from the urban to the rural areas (World Bank 2007a).

The skill shortages have been amplified by a cumbersome matching process where due to the lack of functioning labor market offices skilled workers are not aware of vacancies. In turn, employers posting the vacancies may not know about available skilled workers. The existing employment exchanges are rarely used, as job seekers search through relatives, stop by at work sites, or start their own enterprise. In addition to scarcity of jobs, the declining vacancy-tounemployment ratios posted by agencies reflect the reduced trust of firms in agencies' services (Denu et al, 2005).

Figure 3. Total and Youth Unemployment Rates by Urban Centers, 2005

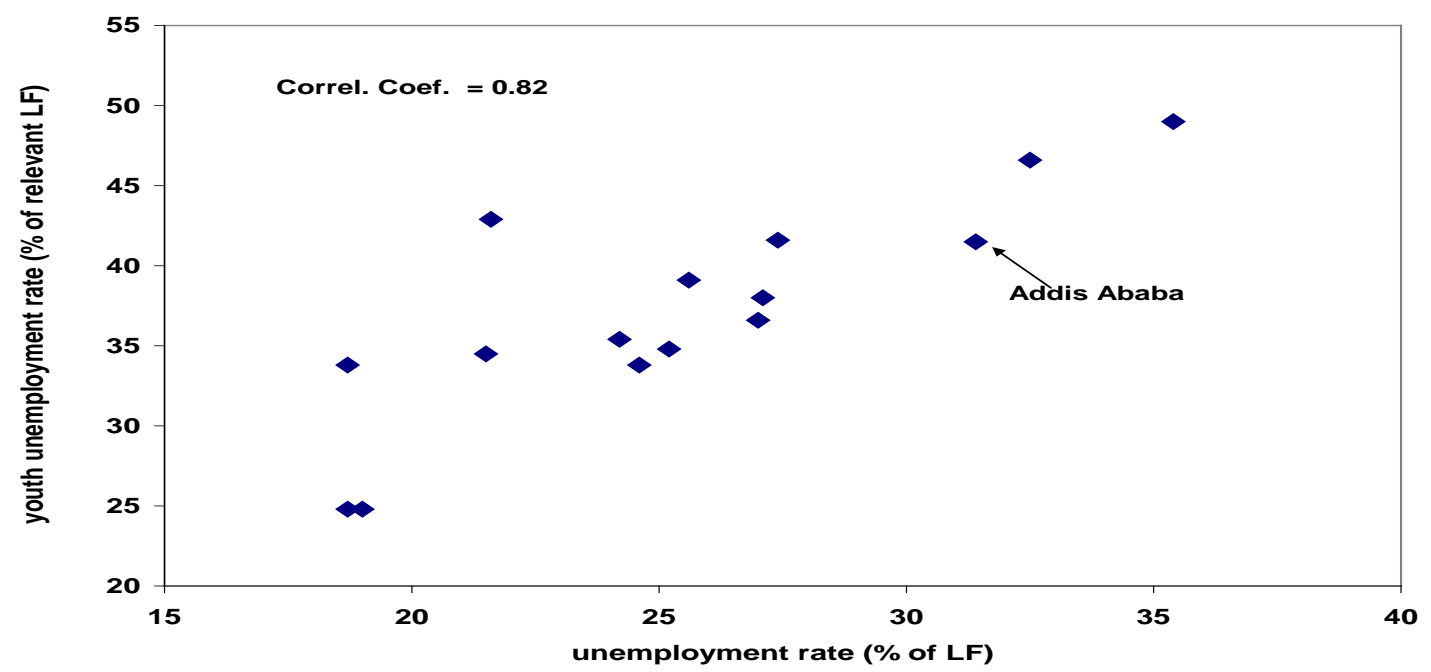

Source: Central statistical office and author’s calculations. 1/ Urban centers have above 2000 inhabitants.

\section{Large and Dualistic Informal Sector}

Similarly to other low-income countries, the informal sector accounts for a large share of the Ethiopian economy - World Bank (2009) found the informal sector to account for 45-50 percent of employment in the urban areas. The majority of SMEs operate in the informal sector, which consists mostly of low-productive - competitive and largely undifferentiated -- firms concentrated in manufacturing and trade. Some highly productive SMEs also operate there, in particular small-scale manufacturing firms. ${ }^{9}$ This more dynamic tier, amounting to about 20 percent of the informal sector, employs more skilled workers. The informal sector in Ethiopia is thus dualistic, albeit more stagnant than in, for example, Mexico (World Bank, 2007b). The

percent of non-agricultural GDP in 2000 (World Bank, 2002). In most transition countries, which started changing from plan to market in early 1990s, the private sector accounted for most of output by the mid-2000.

${ }^{9}$ Gebreeyesus (2008) finds marked differences in productivity across different manufacturing firms, in Ethiopia. 
overall low productivity of the informal sector results in a wage gap with the formal sector (estimated at about $1 / 3$ in 2004).

\section{The Model and Policy Analysis}

The main contribution of this paper is presenting a simple theoretical model illustrating the role of an enabling business environment for stimulating productive entrepreneurship and linking the model with the evidence for Ethiopia. The model, consistent with the stylized facts above, is an extended version of Brixiová (2013) and Snower (1996). ${ }^{10}$ In contrast to these models, our framework includes an informal sector with both self-employed workers and low-productive firms, reflecting the dual nature of the sector. Further, we examine the multiple equilibria that can arise during private sector development. Other key features of the model are (i) costly search of entrepreneurs for business opportunities; (ii) inefficiencies in matching searching entrepreneurs and workers; and (iii) weak business environment that hampers start-ups.

\section{III.1 The Environment}

The population is normalized to one. There are two types of agents, entrepreneurs and workers, with population shares $\mu$ and $1-\mu$, respectively. They live for one period, are endowed with one unit of time and $\bar{w}$ amount of consumption good, and have risk neutral preferences, $E(c)$, where $c$ denotes consumption good and $E$ the expectations agents form at the beginning of the period.

\section{Entrepreneurs}

At the beginning of the period, entrepreneurs search for opportunities to open firms in the private sector. This search costs them $\gamma x^{2} / 2, \gamma>0$, units of the consumption good and results in the probability $x$ of finding a business opportunity with productivity per worker $z_{s}$. In order to turn a business opportunity into a highly-productive firm, the entrepreneur hires $\bar{n}_{s}$ number of skilled workers. ${ }^{11}$ Denoting $m_{p}$ as number of entrepreneurs searching for skilled workers, the matching of the aggregate skilled vacancies, $V_{s}=m_{p} \bar{n}_{s}$, with skilled workers, $N_{s}$, can be described as:

$h=A \min \left[N_{s} ; V_{s}\right]=A \min \left[N_{s} ; m_{p} \bar{n}_{s}\right]$

where $h$ is the total number of matches and $A$ denotes matching efficiency. Entrepreneurs with a high-productivity business opportunity find skilled workers with probability $\rho=A \min \left[\frac{N_{s}}{V_{s}}, 1\right] .{ }^{12}$

10 Brixiová and Égert (2012) analyzed transition economies and Brixiová (2013) developing countries. Snower (1996) studied developed countries. Our model falls into category of search models pioneered by Diamond (1982), Mortensen (1982), and Pissaridies (1985) and developed further by Mortensen and Pissarides (1994) among others.

11 This assumption reflects that productive firms form relationships mainly with productive workers. Fafchamps et al., 2006, examined employee-employer matched data for 11 African countries and confirmed this also for Ethiopia.

${ }^{12}$ As Snower (1996) points out, when firms are imperfectly informed about the availability of skilled workers, even skills that are useful to all firms are not general since not all firms have access to these workers. Such skills are also not specific since more than one firm usually has access to a skilled worker. 
$A<1$ to reflect imperfections in the matching process. These can include transportation bottlenecks or imperfect information where skilled workers do not know about available vacancies and searching entrepreneurs are not aware about searching workers. Labor market measures that raise the matching efficiency include information dissemination and, more generally, job search support, establishment of a national job databases, and quality of labor market placement offices. Transport infrastructure and supply of affordable housing are also important, as they help overcome regional mismatches by linking jobs and workers from different locations.

After finding the highly-productive business opportunity and skilled workers, entrepreneurs decide whether to operate in the formal or informal sector. In the formal sector, they pay start-up cost $c$ (e.g. licensing fee) and produce output according to $y_{s}^{F}=\beta^{F} z_{s} \bar{n}_{s}$. The output thus depends also on the quality of the business environment in the formal sector, $\beta^{F}, 0 \leq \beta^{F} \leq 1{ }^{13}$ Firms in the formal sector pay profit tax $\tau$ and earn after-tax profit:

$\pi^{F}=(1-\tau)\left(\beta^{F} z_{s}^{F} \bar{n}_{s}-w_{s}^{F} \bar{n}_{s}-c\right)$

where $w_{s}^{F}$ is the wage of skilled workers employed by a private firm in the formal sector. It is determined through wage bargaining. The government monitors tax collection and incurs monitoring expenditures $K$.

Entrepreneurs operating in the informal sector do not pay profit taxes. The business environment in the informal sector, $\beta^{I}$, is less favorable than in the formal sector, that is $0<\beta^{I}<\beta^{F}<1$. The output of the highly-productive firm in the informal sector, $y^{I}=\beta^{I} z_{s} \bar{n}_{s}$ and the wage rate, $w_{s}^{I}$, which reflects productivity, are also lower than those in the formal sector. When the government detects a tax evading firm -- with probability $\phi \in(0,1)$-- it confiscates the firm's entire profit. The expected profit of a firm in the informal sector amounts to:

$\pi_{s}^{I}=(1-\phi)\left(\beta^{I} z_{s} \bar{n}_{s}-w_{s}^{I} \bar{n}_{s}\right)$

From (2) and (3) the entrepreneur will operate in the informal sector if the after-tax profit in the formal sector is less than the expected profit in the informal sector, that is if $\pi_{s}^{I}<\pi_{s}^{F}$. To put differently, profit of the entrepreneur employing skilled workers is $\pi_{s}=\max \left[\pi_{s}^{I} ; \pi_{s}^{F}\right] .^{14}$

Those entrepreneurs who do not find highly-productive opportunities or skilled workers open low-productivity firms in the informal sector, with productivity per worker of $z_{u}$. As with the

\footnotetext{
${ }^{13}$ More generally, $\beta^{F}$ reflects quality of formal institutions. Amoros (2009) shows empirically that differences in institutional quality help explain differences in entrepreneurship across countries.

${ }^{14}$ Our model thus reflects observation of Dethier at al. (2011) that not only can better business environments cause firms to be more efficient, but that also that inherently more efficient firms choose better business environments.
} 
highly-productivity firms, their actual productivity is lowered by the business climate factor $\beta^{I}$, $0<\beta^{I}<1$. The entrepreneurs employ unskilled workers, $\bar{n}_{u}$, where $0<\bar{n}_{u}<\bar{n}_{s}$. Since they are also subjected to tax monitoring and full confiscation for tax evasion, their profit amounts to:

$$
\pi_{u}=(1-\phi)\left(\beta^{I} z_{u} \bar{n}_{u}-w_{u} \bar{n}_{u}\right)
$$

where $w_{u}$ is the wage on an unskilled worker in a low-productivity firm, which equals the income, $b$, of the self-employed in the informal sector, and $\phi$ is the probability of being detected. In sum, $z_{s}>z_{u}>b>0$ are productivity levels in high-productivity firms, lowproductivity firms, and of self-employed workers, respectively. ${ }^{15}$

\section{Workers}

When acquiring skills demanded in the highly productive private firms, workers incur cost, $k(q)=\theta q^{2} / 2$ where $\theta>0$ is the cost parameter. Their effort results in probability $q$ of obtaining skills $^{16}$ and probability $\xi=A \min \left[\frac{V_{s}}{N_{s}}, 1\right]$ of finding a job in a highly productive firm. Workers who do not obtain skills or do not find skilled jobs work in the informal sector, either as selfemployed or in a low-productive firm. In both cases they earn income $b<w_{s}$.

While the market for unskilled workers is perfectly competitive, wages for the skilled workers are set through decentralized Nash bargaining between the skilled workers and the highlyproductive private firms. If bargaining does not lead to an agreement, the workers would receive income from self-employment in the informal sector, $b$. The outcome of decentralized bargaining depends on the relative strength of the skilled worker and the firm, $\alpha$ :

$$
w_{s}^{h}=\alpha\left(\beta^{h} z_{s}-\pi_{u}\right)+(1-\alpha) b ; h=F, I
$$

Since $\beta^{F}>\beta^{I}$, the wage of the skilled worker in the formal sector exceeds that of the same worker in the informal sector, in line with productivity differences. The wage gap between skilled and unskilled jobs, $\alpha\left(\beta^{h} z_{s}-\pi_{u}-b\right)$, is again wider for the formal sector workers.

\section{The Labor Market Clearing Conditions}

The characterization of the environment is completed by the labor market equilibrium conditions. Denoting $m_{u}$ as the share of entrepreneurs running low-productivity firms and employ the unskilled workers, the market clearing condition for the entrepreneurs is:

\footnotetext{
${ }^{15}$ For analysis of how size of firms changes with productivity changes and development, see Gollin (2008).

${ }^{16} x$ (and $q$ ) are between 0 and 1. Despite their efforts, workers (entrepreneurs) occasionally fail to acquire skills (find business opportunities).
} 
$\mu=m_{s}^{h}+m_{u}, h=F, I$

Similarly, denoting $n_{s}^{h}=m_{s}^{h} \bar{n}_{s}, h=F, I$, to be the total number of skilled labor employed in the high-productivity private sector (either in the formal of the informal sector), and $n_{u}=m_{u} \bar{n}_{u}$ as total unskilled labor in the low-productivity informal private firms, and $n_{i}$ as total number of self-employed in the informal sector, the labor market equilibrium condition for workers is:

$1-\mu=n_{s}^{h}+n_{u}+n_{i}, h=F, I$

\section{III.2 Multiple Equilibria}

In the following paragraphs, we derive equilibrium conditions based on (2) - (7) and show that the economy has multiple equilibria - a low productivity trap and high productivity equilibrium.

An equilibrium in this economy is defined as an allocation of entrepreneurs and workers and wage rate such that: (i) each entrepreneur chooses the effort $x$ put into search for business opportunities; (ii) each workers chooses effort $q$ put into acquiring skills; (iii) wage rate is set through Nash bargaining as in (5); and (iv) labor market clearance conditions are met. ${ }^{17}$

Proposition 1 In equilibrium, the marginal cost of entrepreneur's search for a business opportunity equals the net profit from search, while the worker's marginal cost of acquiring skills equals the expected difference between a skilled wage and alternative income, given by: ${ }^{18}$

$$
\begin{aligned}
& \not x=\rho\left(\pi_{s}-\pi_{u}\right)=A \min \left[\frac{(1-\mu) q}{\mu x \bar{n}_{s}} ; 1\right]\left(\pi_{s}-\pi_{u}\right) \\
& \theta q=\xi\left(w_{s}-b\right)=A \min \left[\frac{\mu x \bar{n}_{s}}{(1-\mu) q} ; 1\right]\left(w_{s}-w_{u}\right) \\
& w_{s}=\bar{p} w_{s}^{F}+(1-\bar{p}) w_{s}^{I}, \quad \text { and } \\
& \bar{p}=\left\{\begin{array}{cc}
1 & \text { if } \pi_{s}^{F} \geq \\
0 & \pi_{s}^{I} \\
0 \text { otherwise }
\end{array}\right.
\end{aligned}
$$

where $w_{s}^{h}, h=F, I$, is specified in (5).

Proof. Equations (8) and (9) can be obtained by solving entrepreneur's and worker's problems detailed in Annex I, together with the labor market clearing conditions (6) and (7). In (8), $\gamma x \geq 0$

17 It is straightforward to show that depending on the parameters, the model either has (i) a unique 'lowproductivity' equilibrium where workers and entrepreneurs exert zero effort or (ii) one 'low productivity' and one 'high productivity' equilibrium with positive efforts by workers and entrepreneurs.

${ }^{18}$ In (8) and (9), the number of skilled vacancies is $V_{s}=\mu x \bar{n}_{s}, h=F, I$, where $m_{p}=\mu x$ is the number of entrepreneurs who found highly productive business opportunity that to operate in sector $h$. Similarly, the number of skilled workers searching is $N_{s}=(1-\mu) q ; h=F, I$. 
denotes the marginal cost of entrepreneurial search and Equation (11) determines that the highly productive private firms will operate in the formal sector as long as profit from doing so is equal or exceeds the expected profit in the informal sector. The wages of skilled workers are then set by (10) and (5).

The equilibria are formed at the intersections of the entrepreneurs' search curve and workers' training curve. Equations (8) - (11) can lead to 2 equilibria: a low productivity trap, where entrepreneurs do not exhort any effort to create productive firms and high productivity equilibrium with positive effort by entrepreneurs.

\section{Low Productivity Trap}

The first equilibrium is the low productivity trap, where - under a shortage of private firm, i.e. $\mu x \bar{n}_{s}<(1-\mu) q$ - the business environment (i.e. tax rates, start - up cost, search cost) is such that $\pi_{s}<\pi_{u}$. (8) shows that entrepreneurs will not search for highly productive business opportunities, i.e. $x=0$. From (9), workers will not acquire skills i.e. $q=0$. The economy will thus consist of low-productive firms and unskilled workers, operating in the informal sector. ${ }^{19}$

\section{High Productivity Equilibrium}

The second, high productivity equilibrium, lies above the low productivity trap and comprises both positive entrepreneurial search and workers' learning efforts $(x, q>0)$. A pre-condition for reaching this equilibrium is a business environment conducive enough so that profits in the highly productive private firms employing skilled workers exceed those in less productive firms with unskilled workers, i.e. $\pi_{s} \geq \pi_{u}>0$. In this equilibrium, the economy consists of both high and low productivity private firms as well as self-employed workers in the informal sector.

\section{III.3 Policy Analysis}

In this section, we relate the key parameters of our model to evidence on the business environment in Ethiopia. As Ncube (2005) underscores, the type of education and the environment that individuals are exposed to are critical for their entrepreneurial aptitude. In the Ethiopian public universities, entrepreneurship is still in its early phase of development and concentrated mostly in business schools and agricultural colleges. Entrepreneurship promotion centers are also scarce. The country thus needs to integrate entrepreneurship in the curricula while establishing centers of entrepreneurial excellence (Gerba, 2012).

For each potential entrepreneur, the entrepreneurship process starts with search for business opportunity. After such opportunities are identified, the entrepreneurs need to turn them into productive firms. At this stage, they can be hampered by cumbersome registering and licensing procedures, stringent hiring regulations, and the lack of skilled workers, among other factors. The ability of the legal framework to protect property rights is equally important, as it influences

\footnotetext{
${ }^{19}$ Specifically, in an economy with no highly productive private firms, all entrepreneurs and workers operate in the informal sector, either running low productivity firms or being self-employed and earning income $b$.
} 
the expected profit and hence effort that entrepreneurs put into search. The entrepreneurs also consider the state of the financial infrastructure, control of corruption, effectiveness of the government, and efficiency of administration during their start-up phase (Ncube, 2005).

The challenging business climate including high tax rates, weak monitoring of tax evasion and strong bargaining power of skilled workers may also drive high productivity firms into the informal sector. By lowering effective productivity, all these factors then also lower wages of skilled workers and discourage them from acquiring skills.

\section{Improving the Business Environment}

Sections below thus examine the impact of improving the business environment on (i) entrepreneurs' search for highly-productive business opportunities; (ii) their decision to operate in the informal sector and (iii) workers' effort to acquire skills.

Proposition 2. A shortage of skilled vacancies, $(1-\mu) q<\mu x \bar{n}_{s}$ and a better business environment (e.g. higher $\beta^{F}$ and lower $\gamma$ and $\tau$ ) will encourage entrepreneurs to intensify their search effort $(x)$ for productive business opportunities, leading workers to acquire additional skills.

Proof. From (2) $\frac{\partial \pi_{s}^{F}}{\partial \beta^{F}}>0$ and $\frac{\partial \pi_{s}^{F}}{\partial \tau}, \frac{\partial \pi_{s}^{F}}{\partial \gamma}<0$. From (8) the entrepreneurial search effort $x$ becomes $x=A\left(\pi_{s}^{F}-\pi_{u}\right) / \gamma$ in the case of shortages of skilled vacancies. Hence $\frac{\partial x}{\partial \beta^{F}}>0$ and $\frac{\partial x}{\partial \gamma}, \frac{\partial x}{\partial \tau}<0$. From (9) then $\frac{\partial q}{\partial x}>0$.

A more intense search by entrepreneurs and additional learning efforts by workers will result in a higher number of productive firms, increased output, and additional productive employment. Policy makers should thus have strong incentives for preferring the equilibrium with positive searching and learning efforts (e.g., $x, q>0)$ to the one with no efforts $(x=q=0)$ and facilitate it through creating an enabling business climate.

Proposition 3. A better business environment (e.g. higher $\beta^{F}$ and lower $\tau$ ) will encourage entrepreneurs to operate in the formal sector, i.e. $\bar{p}=1$.

Proof. This result follows directly from $\frac{\partial \pi_{s}^{F}}{\partial \beta^{F}}>0, \frac{\partial \pi_{s}^{F}}{\partial \tau}<0$ and from (11).

\section{Reforming Property Rights}

Unclear property rights, which imply a possibility of expropriation (where $\beta^{F}=0$ ), are an important component of the business climate in Ethiopia. Denoting probability of expropriation as $\psi$, the efficiency coefficient in the production function changes to $\bar{\beta}^{F}=(1-\psi) \beta^{F}+\psi 0$. Entrepreneurs are more likely to opt for the informal sector, as the expected profit in the formal 
sector is reduced by the possibility of expropriation. Even if they do not opt for the informal sector, the entrepreneurs will lower their search effort. The reverse also holds - if improvements to property rights are sufficiently large, entrepreneurs who would otherwise opt for the informal sector will increase their search effort and opt for the formal sector.

Due to frictions in matching, search cost, and weaknesses in the business climate (including property rights), the equilibrium conditions (8) - (11) lead to suboptimal outcomes in terms of workers' and firms' efforts and the number of productive SMEs, skilled employment and output. Because of weak business environment, entrepreneurs under-invest in searching for business opportunities relative to the effort they would exhort in a more conducive climate. The impact of the low number of private firms on employment is amplified by imperfect information in the labor market. Workers are uncertain about finding skilled jobs and under-invest in training.

Besides hampering entrepreneurs' search for business opportunities, the challenging business climate, weak monitoring of tax evasion and bargaining power of workers may drive high productivity firms into the informal sector. By lowering productivity, these factors also lower wages of skilled workers and discourage them from acquiring skills.

\section{III.4 Illustrative Numerical Solution}

To illustrate the impact of policies such as improved functioning of the labor market, $A$, and a better business environment, $\beta^{F}$, as well as lower cost of search for business, $\gamma$, and reduced profit tax $\tau$, this section provides a numerical example. The baseline parameters are set in Table 3 ; these values were set to yield the share of informal sector employment in total employment of 50 percent and of formal sector firms in total firms of 29 percent. $^{20}$

Table 3. Baseline Parameters

\begin{tabular}{|l|l|l|l|l|l|l|l|l|l|l|l|l|l|l|}
\hline Parameter & $\mathrm{A}$ & $\mu$ & $\phi$ & $\theta$ & $\gamma$ & $\beta^{F}$ & $\beta^{I}$ & $\alpha$ & $n_{s}$ & $n_{u}$ & $z_{s}$ & $z_{u}$ & $b$ & $\tau$ \\
\hline Value & 0.5 & 0.3 & 0.1 & 0.1 & 1 & 0.55 & 0.4 & 0.5 & 4 & 2 & 2 & 1 & 0.2 & 0.35 \\
\hline
\end{tabular}

The indicative elasticity of informal sector employment to changes in each of the business environment variable $\left(A, \tau, \gamma, \beta^{F}\right)$ is calculated by changing values of these variables by 20 percent and computing the new informal employment rate:

The results in Table 4 confirm that improvements in the business climate would raise number of highly-productive firms and high-skilled/high-wage employment. In the example, the 20 percent improvement would lower low-skilled/low-wage employment in the informal sector by 27 percent, with a corresponding increase in employment in the formal sector. Another effective way of raising productive, formal sector employment are improvements in the labor market functioning, including through provision of information and reducing costs of job search. As Table 4 illustrates, reduced costs of entrepreneurial search would increase number of highly productive firms and skilled employment (in either formal or informal sector).

\footnotetext{
${ }^{20}$ Parameters are chosen to match the limited available information. For example, the wage of unskilled workers in the informal sector amounts to 30-40 percent of the wage of the skilled workers, and the wage gap between skilled workers in the formal and informal sector. 2005, is 30 percent.
} 
Table 4. Elasticities of Key Outcomes w.r.t. Changes in the Business Environment

\begin{tabular}{|l|c|c|c|c|}
\hline Variable & $\begin{array}{l}\text { New } \\
\text { value }\end{array}$ & $\begin{array}{l}\text { New share } \\
\text { of formal } \\
\text { firms }\end{array}$ & $\begin{array}{l}\text { New share } \\
\text { of informal } \\
\text { employment }\end{array}$ & $\begin{array}{l}\text { Elasticity of informal and } \\
\text { unskilled employment to 20 \% } \\
\text { change in variable }\end{array}$ \\
\hline & & \multicolumn{2}{|c|}{ \% of total } & \% change \\
\hline $\mathrm{A}$ & 0.60 & 35 & 40 & -20.0 \\
\hline$\gamma$ & 0.29 & 31 & 47 & -6.4 \\
\hline$\beta^{F}$ & 1.20 & 32 & 45 & -27.4 \\
\hline
\end{tabular}

IV. Confronting the Results with Stylized Facts from Developing Countries

This section seeks to summarize available evidence from developing countries regarding the impact of the business environment on entrepreneurial start-ups. Areas considered are: (i) procedures to start a business; (ii) tax regime and rates; (iii) quality of the regulatory environment; and (iv) the rule of law.

\section{IV.1 Procedures for Starting a Business and Tax Regime}

The impact of the business climate on new firm entry and productivity in developing countries has been shown empirically at the national and firm level (Fagio and Konings, 2003; Klapper, Lavean and Rajan, 2005; Dollar et al., 2005; Lopez-Garcia, 2005; Mitra, Murayev and Schafer, 2009; and Baliamoune-Lutz, 2009). The Doing Business 2013 reconfirms the role of the environment for starting a business and the tax regime in determining the entry and growth of SMEs.

Figure 4a shows that easier procedures to start a business and an enabling tax regime may be accompanied by higher SME entry in developing countries. This suggests that Ethiopia could raise its private firm creation especially by easing procedures on starting a business. Further improvements in the tax regime could be also helpful for developing the private sector.

\section{IV.2 Quality of Regulations and the Rule of Law}

Beyond 'Doing Business' database, the World Bank Governance Indicators database can provide additional insights into factors that encourage business start-ups. The indicator of the regulatory quality reflects perceptions of the ability of the government to formulate and implement sound policies and regulations that support private sector development. Similarly, the rule of law indicators measures perceptions of enterprises about the extent to which society adheres to laws and can enforce contracts, such as property rights.

Figure 4a. SME Start-ups and Regulations for Starting Business \& Paying Taxes 1/ 


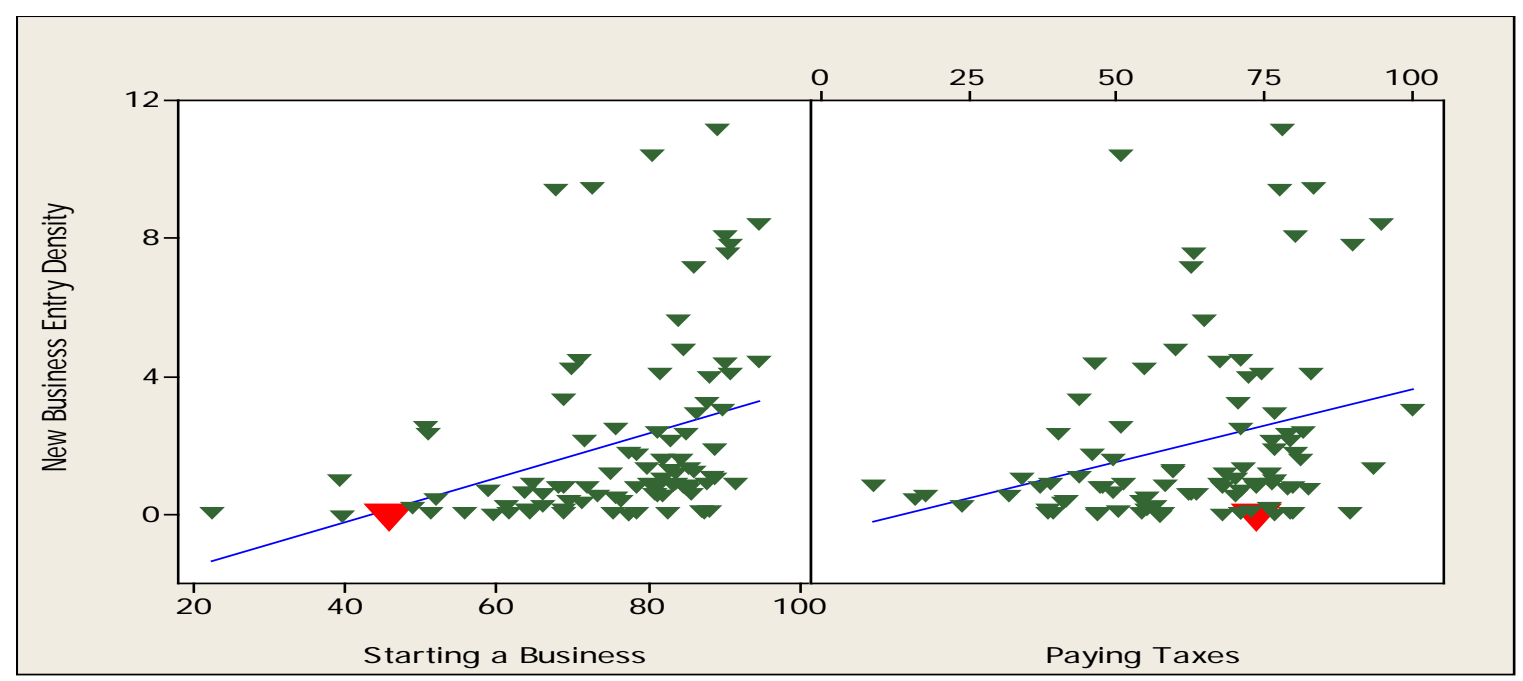

Source: Authors' calculations based on World Bank Entrepreneurship and Doing Business databases. 1/ Correlation coefficients for entrepreneurship with (i) starting a business and (ii) paying taxes are 0.34 and 0.29 , respectively, at $1 \%$ significance level.

Figure 4b. SME Start-ups and Regulatory Quality \& the Rule of Law 1/

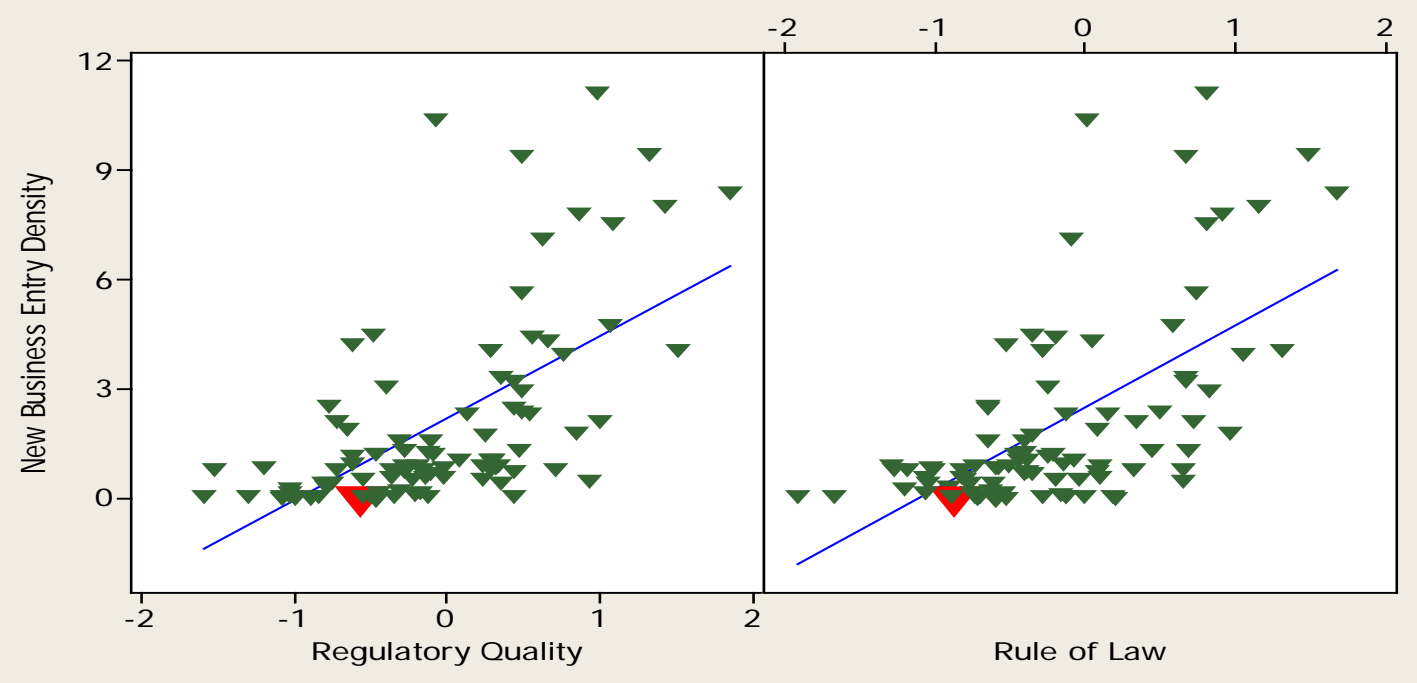

Source: Authors' calculations based on the World Bank Entrepreneurship and Governance databases. 1/ Correlation coefficients for entrepreneurship and (i) regulatory quality and (ii) the rule of law are 0.61 and 0.62 , respectively, at $1 \%$ significance level.

Note: The sample consists of 96 developing and emerging market countries (including 22 African countries) from the World Bank's Entrepreneurship Database. New Business Entry Density is the number of newly registered companies per 1,000 working-age people as recorded in 2011. Both starting business and paying taxes are expressed as closeness to the frontier, in percent, with $100 \%$ being at the frontier, for period 2008 - 2012. Values for the governance indicators range from -2.5 to 2.5, for period 2008 - 2011.

Weak property rights can be particularly damaging to private firm creation as they directly raise possibility of losses, including through expropriation. Even without expropriation, profitability is reduced due to increased uncertainty. Data in Figure 4b show that weaker adherence to rule of law is associated with fewer entrepreneurial start-ups in developing countries. In addition, a positive correlation can be seen between the quality of regulations and firm start-ups. 
In Ethiopia, these observations provide justification for further strengthening of the rule of law, especially property rights, and improving the regulatory environment, especially start up procedures. Other elements/more general reforms for creating an 'enabling entrepreneurship conditions' also need to be in place. These include macroeconomic and political stability, access to credit, and an educational system that would instill entrepreneurial attitudes from early on. As also shown in our model, training for both entrepreneurs and workers, accompanied by help with job or entrepreneurial search, are also likely to stimulate entrepreneurial start-ups.

\section{Conclusions}

In this paper, we first presented several stylized facts about Ethiopia's growth, underscoring that the impressive rate may not be sustainable unless the future growth is more broad-based and private sector-led. High-value added entrepreneurship in particular could play a greater role in raising the economy's output and productivity. Utilizing the World Bank Doing Business Report 2013, Africa Competitiveness Report 2013, and the World Bank 2011 Enterprise Survey of Ethiopia, among other sources, we also documented some of the main obstacles that Ethiopian entrepreneurs face, especially at the start-up stage. Reflecting these facts, we then developed a model of entrepreneurial start-ups where an equilibrium outcome could be a low-skill, lowproductivity trap. We showed that an improved business environment would foster creation of high-productivity private firms, leading to increased aggregate output and employment.

Many African countries would benefit from addressing the remaining obstacles to private sector activities, such as high costs of starting a business, weak property rights, burdensome profit tax rates, unstable tax regimes, and limited access to finance. In the case of high-tech SMEs, skill shortages among entrepreneurs and workers may need to be tackled to foster innovation and high value-added activities. Stronger institutions, including business service providers and those channeling information about business and funding opportunities would also encourage productive entrepreneurship. These and other constraints to entrepreneurship in various African regions, countries, and sectors could be a topic for further research. 


\section{Annex I -- Entrepreneurs' and Workers’ Optimization Problems}

At the beginning of the period, firms and workers decide how much effort to put into search for business opportunities and training, respectively. The entrepreneurs' decision to search for a business opportunity and open a highly-productive private firm is:

$$
\begin{gathered}
\max E(c) \\
\text { s.t. } c+\frac{x^{2}}{2 \gamma} \leq \bar{w}+x \rho \pi_{s}+(1-x \rho) \pi_{u} \\
c>0 ; \quad 0 \leq x \leq 1 .
\end{gathered}
$$

where $\rho=A \min \left[\frac{N_{s}}{V_{s}} ; 1\right]$ is the probability that the entrepreneur who found highly productive business opportunity also finds skilled workers and $\pi_{s}=\max \left[\pi_{s}^{I} ; \pi_{s}^{F}\right]$ implies that the entrepreneur operates in either the formal sector or the informal sector.

Similarly, the worker's decision to obtain training can be described by:

$$
\begin{gathered}
\max E(c) \\
\text { s.t. } \quad c+\frac{q^{2}}{2 \theta} \leq \bar{w}+q \xi w_{s}+(1-\xi q) b \\
\mathrm{c}>0 ; 0 \leq q \leq 1 .
\end{gathered}
$$

where $\xi=A \min \left[\frac{V_{s}}{N_{s}} ; 1\right]$ is the probability that the skilled worker will find a skilled job and $w_{s}=p w_{s}^{F}+(1-p) w_{s}^{I}$, with $\mathrm{p}$ denoting probability that the firm which employs the skilled worker operates in the formal sector. The worker takes this probability as given. 


\section{References}

African Development Bank, OECD, UNDP and UNECA (2012) and (2013), African Economic Outlook, AfDB: Tunis, OECD: Paris, UNDP: New York and UNECA: Addis Ababa.

Amoros, J. A. (2009), 'Entrepreneurship and quality of institutions: A developing-country approach’, UNU-WIDER Research Paper, No. 2009/07.

Arruňada, B. (2007), 'Pitfalls to avoid when measuring institutions: Is Doing Business damaging business?’ Journal of Comparative Economics, Vol. 35(4), 729 - 747.

Baliamoune-Lutz, M. (2009), 'Entrepreneurship and reforms in developing countries', UNUWIDER Research Paper 2009/04.

Brixiová, Z. (2013), 'Modeling productive entrepreneurship in developing countries', Small Business Economics, Vol. 41(1), 183 - 194.

Brixiová, Z. and Égert, B. (2012), 'Business environment, start-ups and productivity during transition’, Macroeconomic Dynamics, Vol. 16 (S2), 213 - 231.

Central Statistical Authority, The Republic of Ethiopia (2003 - 2012), 'Various surveys of national and urban labor markets’, The Ethiopian Central Statistical Authority: Addis Ababa.

Denu, B.; Tekeste, A. and van der Deijl (2005), 'Characteristics and determinants of youth unemployment, underemployment and inadequate employment in Ethiopia', ILO Employment Strategy Paper 2005/07.

Dethier, J.-J.; Hirn, M. and Straub, S. (2011), Explaining enterprise performance in developing countries with business climate survey data', World Bank Research Observer, Vol. 26 (2), 258 309.

Dollar, D.; Hallward-Driemeier, M. and Mengistae, T. (2005) , 'Investment climate and firm performance in developing countries’, Economic Development and Cultural Change, Vol. 54(1), $1-31$.

Diamond, P. (1982), 'Aggregate demand management in search equilibrium', Journal of Political Economy, Vol. 90 (5), 881 - 894.

Egan, V. (2008), 'An exploratory study of small business constraints in Ethiopia: A case study of the retails clothing industry in Addis Ababa’, Curtin University of Technology, Australia.

Fafchamps, M.; Soderbom, M. and Benhassine, N. (2006). Job sorting in African labor markets. Centre for Studies of African Economies, WPS/2006- 12.

Faggio, G. and Konings, J. (2003), 'Job creation, job destruction, and employment growth in transition economies in the 1990s’, Economic Systems (27), 129 - 154. 
Gebreeyesus, M. (2008), 'Firm turnover and productivity differentials in Ethiopian manufacturing', Journal of Productivity Analysis, 29, 113 - 129.

Geda, A. and Degefe, B. (2002), 'Explaining African growth performance: The case of Ethiopia', Paper prepared for the AERC Growth Research Workshop in Nairobi.

Geiger, M.; Moller, L. C. (2013), Ethiopia - Second economic update: laying the foundation for achieving middle income status, World Bank: Washington, DC.

Gelb, A.; Mengistae, T.; Ramachandran, V., and Shah, M. K. (2008), 'To formalize or not to formalize? Comparisons of microenterprise data from Southern and East Africa', Center for Global Development Working Paper No. 175.

Gerba, D. T. (2012), 'The context of entrepreneurship education in Ethiopian universities', Management Research Review, Vol. 35 (3/4), 225 - 244.

Gollin, D. (2008), 'Nobody’s business but my own: self-employment and small enterprise in economic development', Journal of Monetary Economics, Vol. 55, 219-233.

Hanusch, M. (2012), 'The doing business indicators, economic growth and regulatory reforms’, World Bank Policy Research Paper 6176.

International Monetary Fund (2012), 'The Federal Democratic Republic of Ethiopia: 2012 Article IV Consultation’, IMF Country Report No. 12/287.

Klapper, L.; Laeven, L. and Rajan, R. (2006), 'Entry regulation as a barrier to entrepreneurship', Journal of Financial Economics, 82, 591-629.

Lopez-Garcia, P. (2006), 'Business environment and labor market outcomes in Europe and Central Asia Countries’, World Bank Policy Research Working Paper No. 3885.

Mitra, P.; Muravyev, A. and Schaffer, M. (2009), 'Convergence in Institutions and Market Outcomes: Cross-country and Time-series Evidence from the Business Environment and Enterprise Performance Surveys in Transition Economies', World Bank Policy Research Working Paper, No. 4819.

Mortensen, D. (1982), 'The matching process as a non-cooperative/bargaining game', in The Economics of Information and Uncertainty, J. McCall, ed., NBER (ISBN 0-226-55559-3).

Mortensen, D. and Pissarides, C. A. (1994), 'Job creation and job destruction in the theory of unemployment’, Review of Economic Studies Vol. 61 (3), 397 - 415.

Ncube, M. (2005), 'Economic growth, entrepreneurship and the business environment in Africa', Economic Research Southern Africa, Working Paper No. 30. 
Pinheiro-Alves, R. and Zambujal-Oliviera, J. (2012), 'The Ease of Doing Business Index as a tool for investment location decisions’, Economics Letters 117, 66 - 70.

Pissarides (1985), 'Short-run equilibrium dynamics of unemployment, vacancies, and real wages’, American Economic Review, Vol. 75(4), 676 - 690.

Rogerson, C. M. (2001), 'In search of the African miracle: debates on successful small enterprise development in Africa’, Habitat International, Vol. 25, 115-142.

Snower, D., (1996), 'The low-skill, bad-job trap', in: Booth, A., Snower, D. (Eds.), in Acquiring skills: Market Failures, their Symptoms and Policy Responses, Cambridge University Press, New York, 109-128.

Sonobe, T.; Akoten, J. E.; and Otsuka, K. (2009), 'An exploration into the successful development of the leather-shoe industry in Ethiopia', Review of Development Economics, 13, 719-736.

Sutton, J. and Kellow, N. (2010), ‘An Enterprise map of Ethiopia’, ISBN 978-1-907994-00-5 International Growth Center.

USAID (2009), 'High-end Ethiopian handbags enter the global leather market', USAIDFrontlines: www.usaid.gov/press/frontlines/fl_apr09/p8_ethiopia.html.

World Bank (2013), Doing Business 2013: Smarter Regulations for Small and Medium-Sized Enterprises, World Bank: Washington DC.

World Bank (2009), Ethiopia - Toward the Competitive Frontier: Strategies for Improving Ethiopia’s Investment Climate, World Bank: Washington, DC.

World Bank (2007a), Ethiopia - Urban Labor Markets: Challenges and Prospects, Poverty Reduction and Economic Management Unit Report \#38665-ET.

World Bank (2007b), Accelerating private sector-led growth, in Ethiopia - Accelerating Equitable Growth: Country Economic Memorandum, World Bank: Ethiopia.

World Bank (2002), Tanzania at the Turn of the Century: Background Papers and Statistics, World Bank: Washington DC. 